\title{
Small hyotheriine suids (Mammalia, Artiodactyla) from the late early Miocene of Turkey and a short overview of early Miocene small suoids in the Old World
}

\author{
Maëva J. Orliac, Levent Karadenizli, Pierre-Olivier Antoine, and Sevket Sen
}

\begin{abstract}
Suoids are conspicuous components of late early Miocene faunas in Europe, Asia, and Africa. Strikingly, despite a rich fossil record at the Old World scale, no early Miocene suoid remains were known thus far from Anatolia, a region located at the crossroads between Africa, Arabia, Asia, and Europe. Here we describe a fragmentary cranium, mostly preserving the palate, and a dp4 of small suids from the Şemsettin locality in the Çankiri-Çorum Basin, north Central Anatolia. These remains document the first suoids ever recorded in the Early Miocene of Turkey. Both remains are attributed to the subfamily Hyotheriinae. The fragmentary cranium presents an original combination of characters and is attributed to Nguruwe? galaticum sp. nov. The isolated dp4, of much smaller size, is here attributed to another hyotheriine taxon of indeterminate genus and species. Nguruwe? galaticum sp. nov. shows equal affinity with both Asiatic and African Hyotheriinae.
\end{abstract}

Maëva J. Orliac. Institut des Sciences de l'Evolution, UMR 5554 CNRS, IRD, EPHE, Université de Montpellier, Place Eugène Bataillon, 34095 Montpellier cedex 5, France. maeva.orliac@univ-montp2.fr Levent Karadenizli. MTA Genel Müdürlüğü Jeoloji Etütleri Dairesi, Üniversiteler Mahallesi, Dumlupınar Bulvarı, TR-06800, Çankaya-Ankara, Turkey. levent.karadenizli@gmail.com

Pierre-Olivier Antoine. Institut des Sciences de l'Evolution, UMR 5554 CNRS, IRD, EPHE, Université de Montpellier, Place Eugène Bataillon, 34095 Montpellier cedex 5 France. pierre-olivier.antoine@univmontp2.fr

Sevket Sen. Centre de recherches sur la paléobiodiversité et les Paléoenvironnements, UMR 7207 CNRS, UPMC, MNHN, 8 rue Buffon, 75005, Paris, France. sen@mnhn.fr

Keywords: Suidae; Hyotheriinae; Çankiri-Çorum Basin; Central Anatolia; new species

http://zoobank.org/290FE925-4359-4FE3-81C1-00FA7F922FF7

PE Article Number: 18.2.30A

Copyright: Palaeontological Association June 2015

Submission: 27 February 2015. Acceptance: 27 May 2015

Orliac, Maëva J., Karadenizli, Levent, Antoine, Pierre-Olivier, and Sen, Sevket. 2015. Small hyotheriine suids (Mammalia, Artiodactyla) from the late early Miocene of Turkey and a short overview of early Miocene small suoids in the Old World. Palaeontologia Electronica 18.2.30A: 1-18 palaeo-electronica.org/content/2015/1232-turkish-early-miocene-suids 


\section{INTRODUCTION}

The early Miocene interval (c. 23-16 Ma) is a period of intense faunal turnovers and land mammal dispersals between the Afro-Arabian and Eurasian plates (e.g., Madden and Van Couvering, 1976; Tassy, 1990; Antoine et al., 2010, 2013; Sen, 2013). Suoids are conspicuous components of late early Miocene faunas in Europe, Asia, and Africa (e.g., Pickford, 1986; van der Made, 1996a, 1996b; Orliac et al., 2006, 2010a; van der Made, 2010; Pickford, 2011; Antoine et al., 2013). Strikingly, despite such a rich fossil record at the Old World scale, no early Miocene suoid was previously reported from Anatolia, a region located at the crossroads between Africa, Arabia, Asia, and Europe. Here we describe a fragmentary cranium, mostly preserving the palate, and a dp4 of small suids from the Şemsettin locality (Kumartaş Formation), in the Çankiri-Çorum Basin, of north Central Anatolia (Sen et al., 1998; Karadenizli, 2011). These remains document the first suoid record in the Early Miocene of Turkey.

\section{Geological Context}

The Şemsettin mammal locality is situated in the western part of the Çankiri-Çorum Basin (ÇÇB), which is one of the largest Cenozoic basins of Turkey. This basin was formed in the collision zones between the Kirsehir Block and Sakarya Continent during the late Cretaceous, just south to the Izmir-Ankara-Erzincan suture zone (Kaymakçi, 2000; Kaymakçi et al., 2009, 2010). Kaymakçi (2000) distinguished the western part of this basin as Hançili Sub-basin because it is separated from the main ÇÇB by an ophiolitic high, and its sedimentary deposits are different in facies composition from the contemporaneous deposits of the main ÇÇB. However, Seyitoğlu et al. (2009) claimed that the Neogene successions in both basins accumulated within a connected basin that became later separated by an ophiolitic high during the late Pliocene. The Cenozoic infill of the ÇÇB is estimated over $4 \mathrm{~km}$ thick, with only minor sedimentation gaps. The last marine occurrence is dated to the middle Eocene (Bartonian stage), and later deposits of this basin represent fluvial and lacustrine sedimentary environments (Kaymakçi, 2000; Karadenizli, 2011). They are divided into a dozen sedimentary units, one of them being the Kumartaş Formation that includes the Şemsettin mammal locality (Figure 1).

The Kumartaş Formation is composed of massive and bedded conglomerates, bedded or cross-bedded sandstones, and massive mud- stones, representing the deposits of meandering river and flood plain environments (Karadenizli, 2011). It conformably overlies the Kilçak Formation as seen on the outcrops southeast of Kumartaş village or lies directly on the metamorphic basement (Karadenizli et al., 2004; Özcan et al., 2007; Karadenizli, 2011). It grades upward and laterally into the Hançili Formation, which is mainly a lacustrine unit. The Kumartaş Formation occupies large areas in the western part of the ÇÇB. The mammal locality occurs in its lowermost part, at $1.5 \mathrm{~km}$ southeast of Şemsettin village. At the fossiliferous site, the stratigraphy consists of a succession of basal conglomerates (less than $1 \mathrm{~m}$ ) that lie on the metamorphic basement (ophiolites), followed by a thick unit (about $20 \mathrm{~m}$ ) of red beds with sandy-silty intercalations, cross beddings, and small channels. The fossiliferous site is located four $m$ above the base of this bed, and $18 \mathrm{~m}$ below the lacustrine limestone horizon (about eight $m$ thick). The limestone horizon is overlain by fluvial deposits (about $20 \mathrm{~m}$ thick), which grade progressively to greygreen marls and clays typical of the Hançili Formation (Figure 1). The Şemsettin mammal locality was discovered in September 1997. Its geographic coordinates are $40^{\circ} 19^{\prime} 15.1^{\prime \prime} \mathrm{N}$ and $33^{\circ} 20^{\prime} 07.4^{\prime \prime}$ $\mathrm{E}$. It yielded some large and small mammalian remains (Sen et al., 1998). The suoid remains described in the present paper were found during a second visit to the locality in July 1999 by one of us (S. Sen).

\section{MATERIAL AND METHODS}

\section{Material}

The suoid material from Şemsettin described here consists of a fragmentary cranium ( $n^{\circ}$ SMT- 1 ) and an isolated lower fourth deciduous molar $\left(n^{\circ}\right.$ SMT-2) curated at the Natural History Museum of Ankara, Turkey. The small mammal assemblage represented at Şemsettin includes the erinaceid Galerix cf. G. symeonidisi, the soricid Miosorex sp., the sciurid Aliveria sp., the glirid Glirudinus cf. G. euryodon, the cricetid muroid Democricetodon franconius, and the small moschid Micromeryx sp. (Sen et al., 1998; Karadenizli, 2011). This faunal association correlated the Şemsettin assemblage with the Western European mammalian zone MN4, in the late early Miocene (Karadenizli, 2011).

\section{Methods}

Suprageneric systematics among Suoidea follow mostly Orliac et al. (2010a) and partly van der Made (2010). van der Made (2010) considered that 


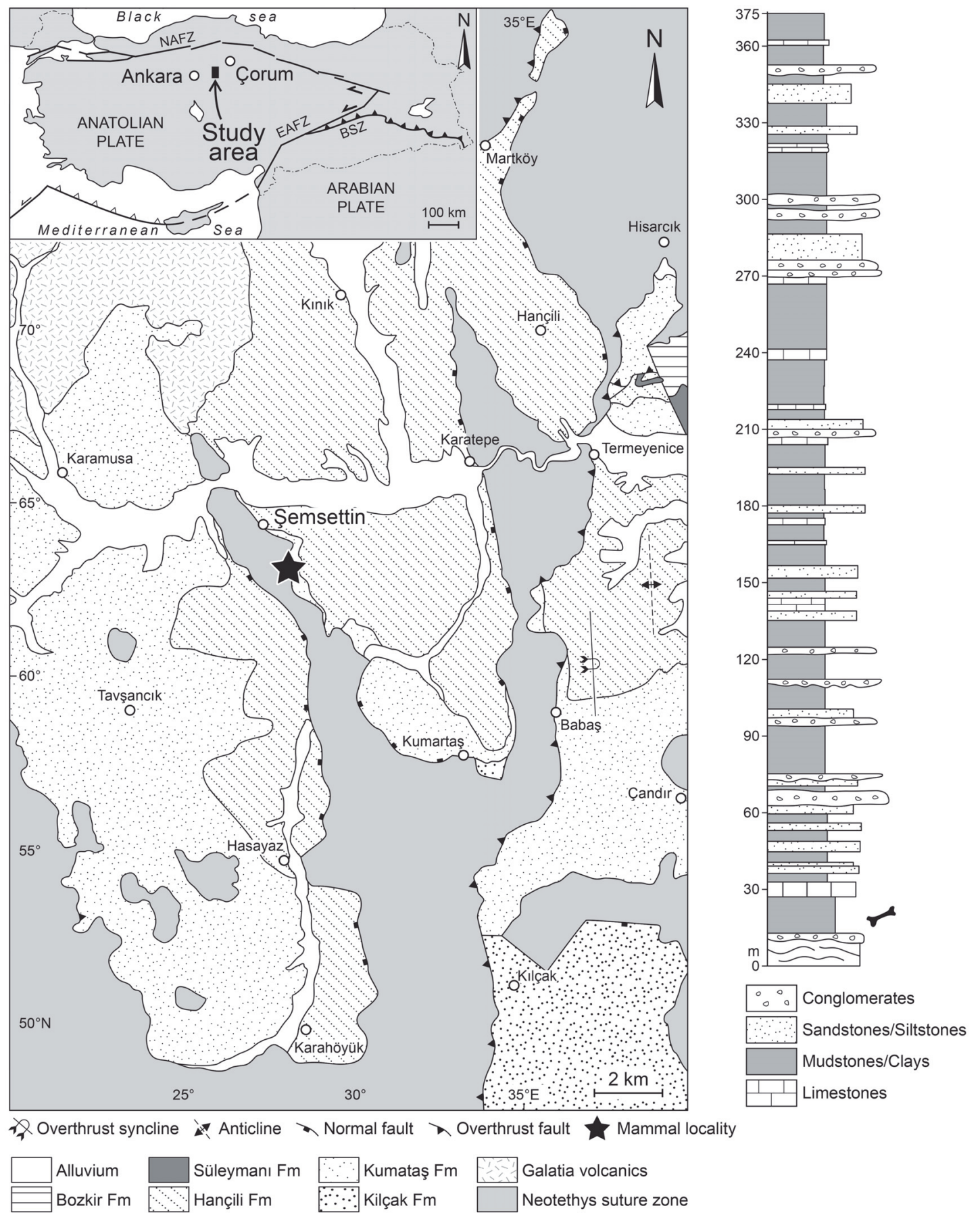

FIGURE 1. Geological map of the region around the Şemsettin locality (modified from Karadenizli et al., 2004 and from Özcan et al., 2007) and lithostratigraphic column across the Şemsettin locality (modified from Karadenizli et al., 2004).

the species Aureliachoerus minus and A. aurelianensis were more closely related to one to another than to any other hyotheriine (which further testified to their congeneric assignment) and named the tribe Aureliachoerini, which he defined as follows: "Hyotheriinae, with an extremely developed sagittal crest and a well-developed postglenoid process " (van der Made, 2010, p. 114). This opinion contrasts with the result of the formal parsimony analysis of Orliac et al. (2006), which found [A. minus $+A$. aurelianensis] to be paraphyletic within Hyotheriinae and led to the erection of the monotypic genus Chicochoerus for $C$. minus. The latter analysis, however, did not include the charac- 
ters of the sagittal crest and postglenoid process mentioned by van der Made (2010). He criticised the results of the phylogenetic analysis proposed by Orliac et al. (2006) on the grounds that (i) some remains from Montréal-du-Gers (the upper canine and the P4) were erroneously attributed to $C$. minus, which led in turn to mistakes in scoring some character states, and (ii) "the concave postcristid of the premolars appears twice in the data matrix (characters 3 and 11)." Nonetheless, the character 3 and 11 of Orliac et al. (2006) are clearly different in their distribution (Orliac et al., 2006, appendix 3), which obviates any univocal interdependence between both characters. In another phylogenetic analysis performed at the suoid level and based on a distinct character set and a wider taxonomic sample, Orliac et al. (2010a, figure 1) also retrieved $C$. minus remote from $A$. aurelianensis within Hyotheriinae. Accordingly, as far as the monophyly of the Aureliachoerini tribe (sensu van der Made, 2010) was not tested and supported by a formal phylogenetic analysis, we have chosen to use here the name $C$. minus proposed by Orliac et al. (2006). Besides, to our knowledge, there are no published cranial remains of $A$. aurelianensis and "A." minus preserving the sagittal crest and/or postglenoid process; indeed, the only published cranium for the genus, figured by Collier and Guex (1977), does not allow any convenient observation. The material from NMB mentioned by van der Made $(2010$, p. 110$)$ shows a sagittal crest which is, to us, not significantly higher than that of $\mathrm{Ngu}$ ruwe namibense $(10 \mathrm{~mm}$, GT 52'05, Pickford, 2008, plate 2). Dental nomenclature follows that of Orliac et al. (2011), mostly based on Boisserie et al. (2010); it also includes some terms adapted from van der Made (1996b). Dimensions are in $\mathrm{mm}$.

To investigate the morphology of the molar roots, before restoration of the fragmentary cranium $n^{\circ}$ SMT-1, a portion of the left upper molar row (broken apart) was scanned in the coronal plane using the high-resolution in vivo micro-tomograph SkyScan 1076 at the Universite of Montpellier, France. The scans resulted in 1157 slices with a resolution of $36 \mu \mathrm{m}$. AVIZO 6.3 (Visualization Sciences Group) software was used for visualization, segmentation, and $3 \mathrm{D}$ rendering. The 3D model of the left upper molar row is available online at MorphoMuseuM.com ID: M3\#16_SMT-1. Dental measurements are provided in Table 1.

Institutional abbreviations. KNM, National Museums of Kenya, Nairobi; MNHN, Muséum National
TABLE 1. Dental measurements of the small suoid remains from Şemsettin in millimeters. * estimated after partly broken material; ${ }^{* *}$ measurement of the base of the teeth (crown broken).

$\begin{array}{ccc}\text { Specimen } & \text { LLL max } & \text { APL max } \\ \text { C (I) } & 6.4 & 7.5 \\ \text { P3(r) } & 7.9^{*} & 9.6 \\ \text { P3(I) } & 8.5 & 9.7 \\ \text { P4 (I) } & - & 8.0^{* *} \\ \text { M1(I) } & 12.2^{*} & 11.1^{*} \\ \text { M2 (I) } & 13.0 & 13.5^{\star} \\ \text { M3 (I) } & 12.4 & 13.9^{* *} \\ \text { dp4 (r) } & 5.7 & 10.9\end{array}$

d'Histoire Naturelle, Paris; UT, University of Thessaloniki.

\section{SYSTEMATIC PALEONTOLOGY}

Order ARTIODACTYLA Owen, 1848

Family SUIDAE Gray, 1821

Subfamily HYOTHERIINAE Cope, 1888

Genus NGURUWE Pickford, 1986

Type species. Nguruwe kijivium (Wilkinson, 1976)

Nguruwe? galaticum sp. nov.

Figures 2.1-3, 2.6-14, 3, 4.1

\section{zoobank.org/F5EE51A1-3F6F-4E7A-BD88-E92349C813FB}

Type specimen. SMT-1, fragmentary cranium preserving portions of the palate, of right and left zygomatic arches, and some fragments of the nasal or lachrymal bone; in situ left M1-M3 (M1 and M3 partly broken) and right $\mathrm{P} 3$, associated left $\mathrm{P} 3$ and right $\mathrm{C}$ isolated.

Type locality. Şemsettin, Çankiri-Çorum Basin, Turkey. Kumartaş Formation, late early Miocene.

Derivatio nominis. Neutral epithet named after " Galatia », name of the area of Çankiri-Çorum Basin at the Greek epoch.

Diagnosis. Hyotheriinae smaller than the species referred to Hyotherium $(H$. meisneri, $H$. major, $H$. soemmeringi, $H$. youngi, and $H$. lacaillei), with no prezygomatic shelf, similar in size to Aureliachoerus aurelianensis and Nguruwe kijivium as regarding the antero-posterior length of comparable cheek teeth; differs from $A$. aurelianensis in having a P3 with no accessory cusp in the postparacrista, and with a wider and shallower lingual basin bordered by a smaller lingual cingulum. Differs from available material of $N$. kijivium in displaying a smoother enamel surface and a paraconule not fused to the anterior cingulum on M2. Differs from 


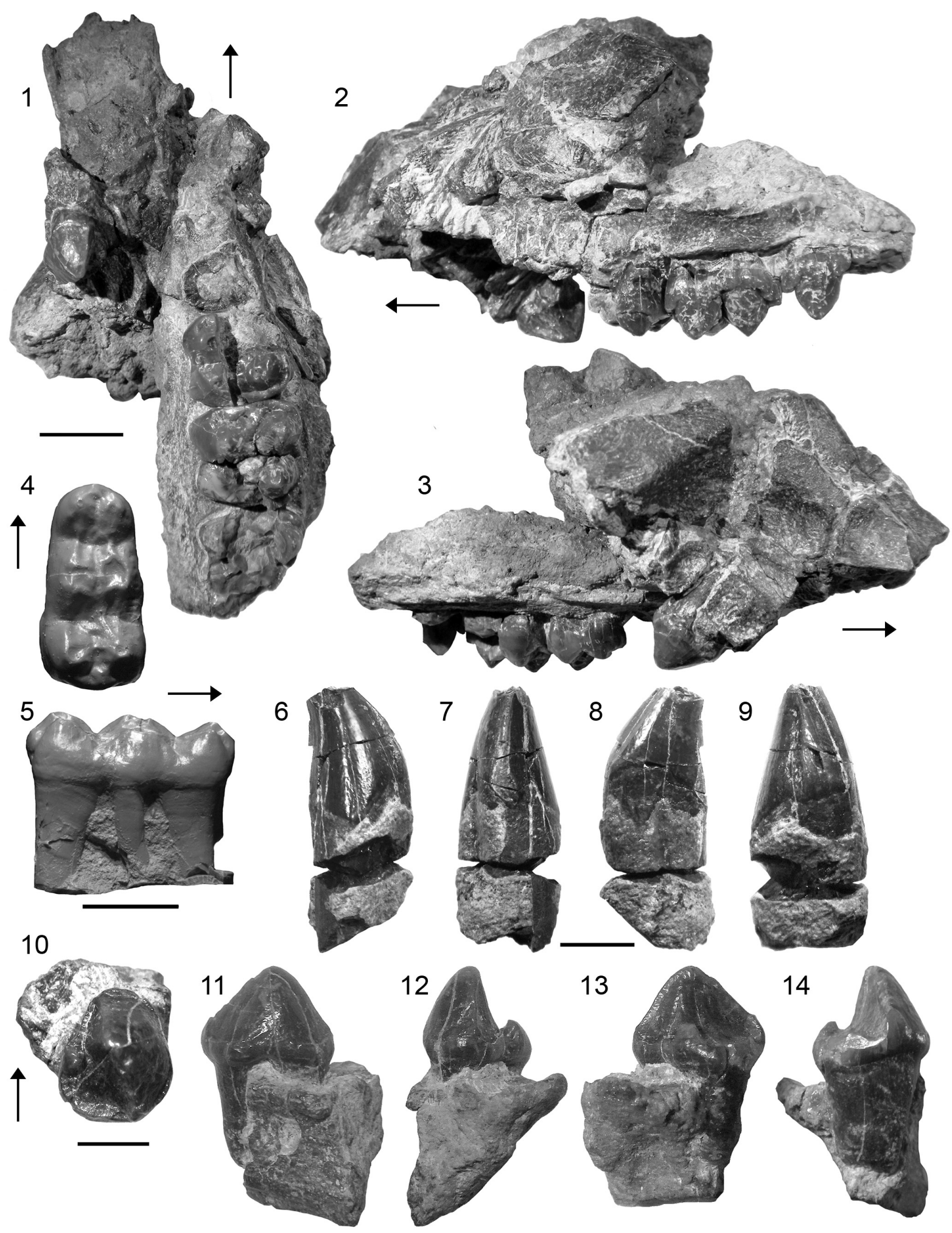

FIGURE 2. Figure 2 Suid remains from Şemsettin, Çankiri-Çorum Basin, north Central Anatolia. Nguruwe? galaticum sp. nov.:1-3, fragmentary cranium, type specimen SMT-1 in 1) occlusal, 2) left lateral, 3) right lateral views; 6-9, right canine associated to SMT-1 in 6) ventral, 7) posterior, 8) lateral, 9) anterior view; 10-14, left P3 associated to SMT-1 in 10) occlusal, 11) labial, 12) anterior, 13) lingual, 14) posterior views. Hyotheriinae gen. et sp. indet: 4-5, isolated right dp4 SMT-2 in 4) occlusal, 5) labial views. Arrows indicate anterior direction for jugal teeth. Scale bars equal 5 $\mathrm{mm}$. 

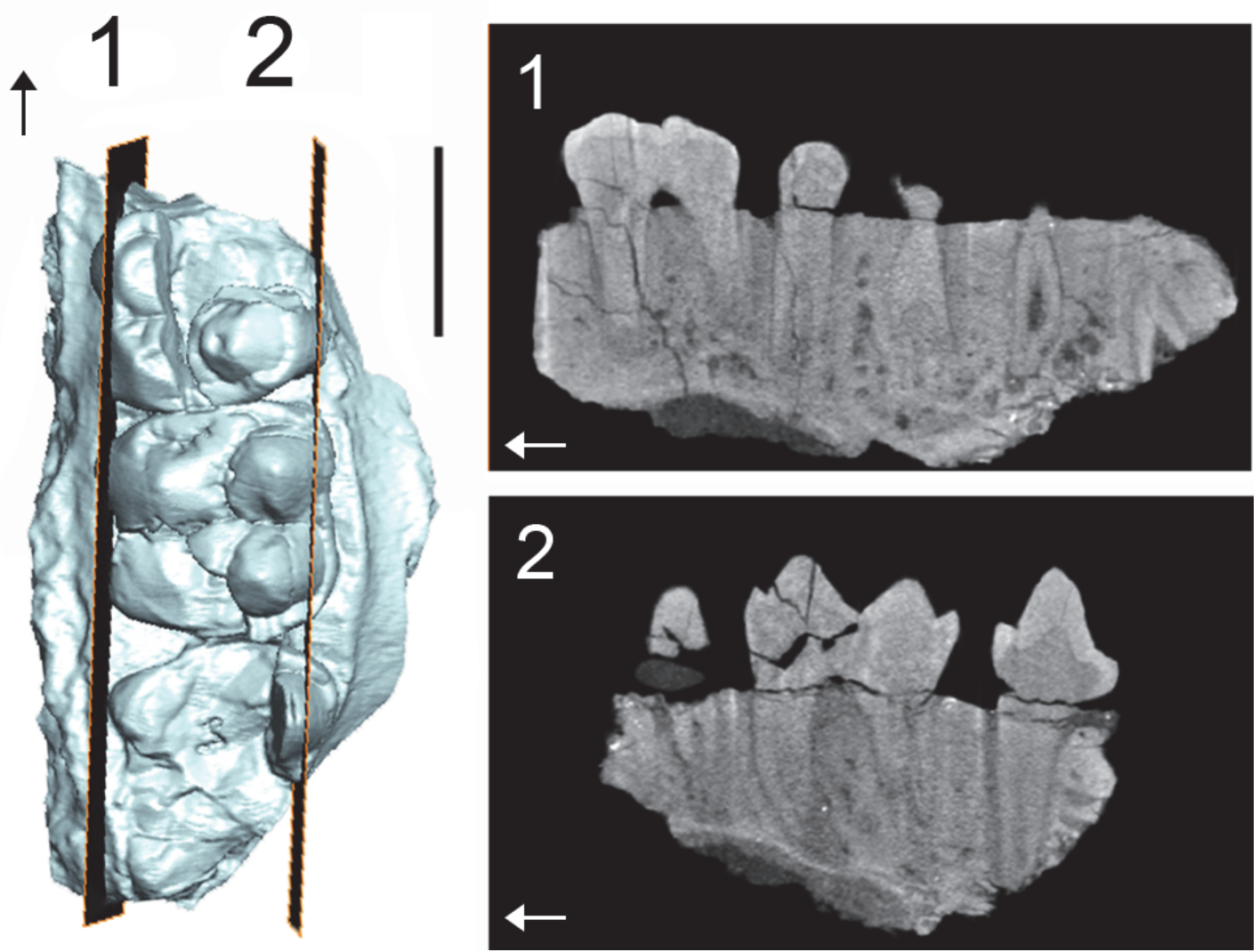

FIGURE 3. 3D reconstruction of SMT-1 from Şemsettin in occlusal view and 1-2) CT scan slide showing root structure at different sections of the specimen: 1) buccal; 2) lingual. Arrows indicate anterior direction. Scale bar equals $10 \mathrm{~mm}$.

Chicochoerus minus and Nguruwe namibense in its larger size.

\section{Description of the Fragmentary Cranium}

The specimen SMT-1 consists of a fragmentary cranium. On the left side, the palate with P3M3 are preserved: (1) On the left side, the palate with P3-M3, and (2) on the right side, a short portion of the palate with P3 (only tooth preserved on this side), the root of the right jugal part of the zygomatic arch, the jugal portion of the left zygomatic arch, and some fragments of the nasal or lachrymal bone. The left side bears the roots of P4, fragmentary M1-2, and an almost completely broken M3 (only the labial wall of the paracone is preserved); the left P3 is set in a small isolated fragment of maxilla. The right canine is also preserved but is no longer in situ. Dental remains are only slightly worn and most of the groove-and-crest pattern is visible. Based on the available remains, the teeth of the fragmentary cranium SMT-1 can be used for taxonomy; what is left of the zygomatic arches, nasal and lachrymal bones are too damaged and deformed to be described. Only the root of the right zygomatic arch warrants description. The ventral surface of the anteriormost end of the zygomatic arch shows the imprints of the $m$. depressor rostri (and maybe $m$. dilatator naris lateralis) on a small concave surface reaching anteriorly the level of P3. This area is overhung by the straight ventral border of the anterior portion of the zygomatic arch. There is no trace of prezygomatic shelf (Figure 2.3).

The right upper canine has most of its crown: only the apex is broken away. It is short, straight, and lingually inflated. Its root has a sulcus on the labial surface, most probably as a relic of the formerly separate roots. The morphology of the canine root suggests that the growth might have been prolonged, but was not continuous like the ever-growing canines of modern suids. The crown/ enamel surface bears an antero-lingual enamel ridge and a posterior one. The lingual side of both ridges is particularly sharp; the enamel is thin on the lingual surface, between the two ridges, compared to that observed on the labial surface of the crown. The anterior ridge is lined by a groove on its ventral surface. The crown has three distinct 

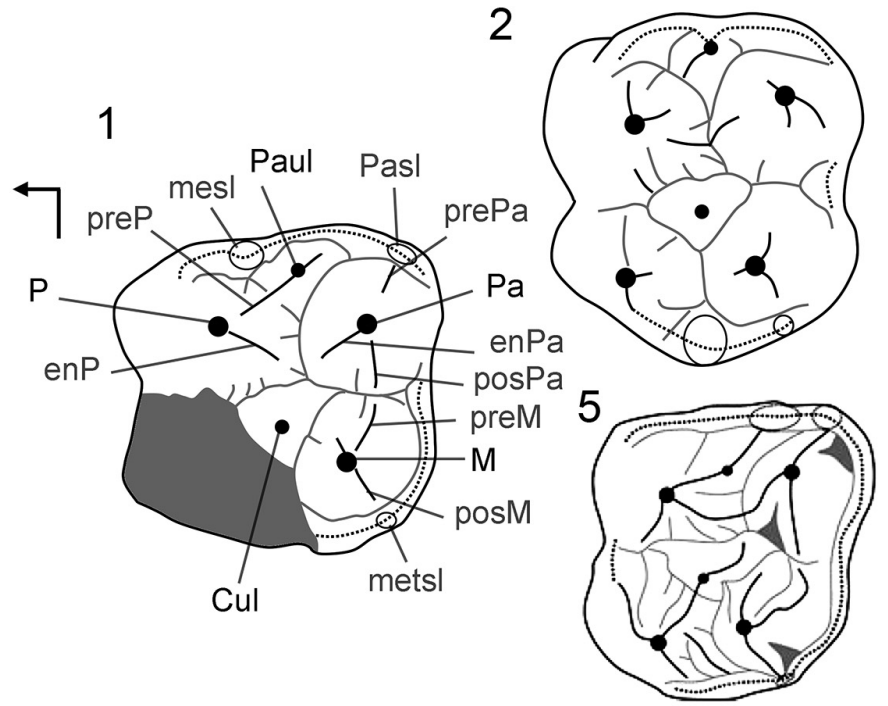
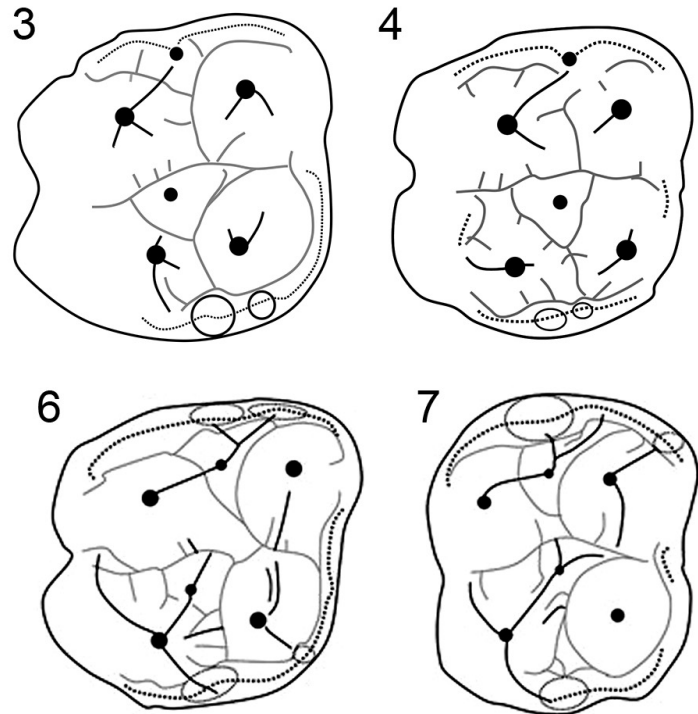

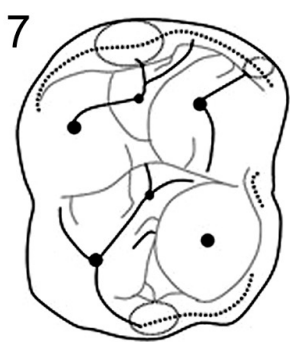

FIGURE 4. Occlusal pattern of the M2 of: 1, specimen from Şemsettin (SMT-1); 2, Aureliachoerus aurelianensis (Suidae, Hyotheriinae, MNHN Ar 2611); 3, Hyotherium meisneri (Suidae, Hyotheriinae, van der Made, 1994, plate IV7); 4, Nguruwe kijivium (Suidae, Hyotheriinae, KNM); 5, Sanitherium (Sanitheriidae, modified after Orliac et al., 2011, figure 5J); 6, Palaeochoerus (Palaeochoeridae, modified after Orliac et al., 2011, figure 5H); 7, Taucanamo (Palaeochoeridae, modified after Orliac et al., 2011, figure 5I). Not to scale. Abbreviations: cul, centroconule; enP, endoprotocrista; enPa, endoparacrista; M, metacone; mesl, mesiostyle; mestl, metastyle; P, Protocone; Pa, paraconule; Pasl, parastyle; Paul, paraconule; posM, postmetacrista; posPa, postparacrista; preM, premetacrista; preP, preprotocrista; prePa, preparacrista.

weakly developed enamel bands: anterior, posterior, and lingual (Figure 2.6-9), the ventral being the larger one. There is a little wear facet on the anterior surface of the crown.

The P3s are preserved on both sides of the specimen. The posterior part of the alveolus of P2 is just anterior to the roots of the P3, without a diastema. P3 bears only one cusp, the paracone, from which run two sharp cristae: the preparacrista connects the anterior cingulum at the anterolingual corner of the tooth, and the postparacrista joins the posterior cingulum at the posterolabial corner of the tooth. The tooth is almost unworn and the postparacrista is finely crenulated, with a small style where it connects to the posterior cingulum. The posterior part of the tooth comprises a wide lingual basin; it is anteriorly bordered by a small accessory cusp, merged with the lingual cingulum. The lingual basin is shallow and in continuity with the slope of the lingual flank of the paracone, its surface bears very small enamel knobs. The cingulum is small and continuous all around P3, with only a slight interruption on the labial surface of the paracone. P3 has two roots: a small anterior one and a wide posterior pillar.
The crown of P4 is totally broken and only its outline and roots can be observed. Three roots are identifiable (two labial and a lingual one).

M1 is badly damaged but the lingual half of the protocone and metacone are preserved, together with the metaconule and parts of the postmetacrista and of the centroconule; the paracone is missing. M2 is the most complete upper molar (the metaconule is missing). By contrast, only half of the paracone of M3 is preserved, while the rest of the crown is broken away. However, the outer profile of the tooth indicates clearly the presence of a posterior lobe. CT scan investigation of the specimen reveals that the lingual and labial roots of the molars are not fused (Figure 3). The upper molars are strongly bunodont. On M2, the paracone bears a very light precrista, a long endocrista that joins the endoprotocrista, and a sharp postparacrista. These crests are underlined by grooves: namely the endoparafossa and preparafossa. A paraconule is present, partly fused to the anterior cingulum and separate from the preprotocrista by a groove. The protocone also bears an endoprotocrista but no postprotocrista. There is no clear endoprotofossa; the preprotofossa is short but deep, the preprotocrista is lined lingually by an ectoprotofossa. The centroconule is large on M2. The 
metacone is preserved on M1-2. It bears two clear cristae: ecto- and premetacrista. The ectometafossa is deep and faces the postparafossa. The presence of the endometacrista is difficult to ascertain; it might be on the edge of the wear facet located on the posterior surface of the metaconid; no trace of a postmetacrista is visible. The metaconule is only partly preserved on M1. The ecto-, pre-, and post-metacristules are visible. The ectometacristule is sharp, lined labially by a deep ectometafossule; it connects a very short lingual cingulum, located at the transverse valley.

The anterior cingulum is thick in all three upper molars; it is continuous with the labial cingulum that extends for the labial side of the tooth on $\mathrm{M} 2$, and most probably on $\mathrm{M} 1$, judging from its extension on the metacone. The posterior cingulum is strong on M1-2. Anteriorly, on M2, the mesiostyle and parastyle are small but identifiable and an ectostyle is present labially at the base of the paracone. A metastyle occurs on M1-M2 at the postero-labial corner. The enamel surface of the upper cheek teeth is slightly rugose.

Family SUIDAE Gray, 1821

Subfamily HYOTHERIINAE Cope, 1888 gen. et species indet.

\section{Description of the Fourth Deciduous Lower Premolar}

In addition to ${ }^{\circ}$ SMT- 1 , the Şemsettin locality has yielded a fourth deciduous lower premolar of a suoid ( $n^{\circ}$ SMT-2). The dp4 is typically three-lobed with two cuspids on each lobe. The tooth bears three root pillars: (i) two major ones, an anterior lying under the anterior lobe and the anterior half of the second lobe, and a more massive posterior one under the posterior lobe, and (ii) a smaller labial one, intercalated between the two major root pillars at the level of the protoconid. The tooth only slightly widens posteriorly, and it presents a slight swelling at the level of the protoconid above the small lingual root. The cusps are wide and rounded, separated by narrow and shallow transverse valleys. There is a clear preparaconulid lying between the primonid (sensu van der Made, 1996b) and the paraconid, and connected to them by cristids. The paraconid bears a clear preparacristid, and a postparacristid divided at its base. The primonid has a complex pattern of cristids with pre-, endo-, and postcristids. Postpara- and postprimocristids join the preproto- and premetacristids, respectively, in continuous crests. The cusps of the second lobe (protoconid and metaconid) are heavily worn, but a complicated pattern of crests is still visible, with pre-, post-, and postectocristids. The protoconid also presents an ectoprotocristid. They are linked by their postcristids posteriorly, at the level of the posterior transverse valley. The grooves of the second lobe (pre-, post-,metafossid, and ecto-, pre-, postprotofossid) are deep. The metaconid bears a sharp and high postectocristid that ends in the transverse valley, just in front of the ectoendocristid. Labially, the postectoprotocristid connects to a very light ectohypocristid. The mesoconulid is not clearly differentiated, and it consists in a crest, low in the posterior valley and connected to the prehypocristid. The hypoconid also bears an endohypocristid connected to the endoentocristid and a posthypocristid that joins the small hypoconulid. There is a slight labial cingulum, between the protoconid and the hypoconid.

\section{DISCUSSION}

\section{Assignment of the Suoid Remains from Şemsettin at the Family and Genus Level: Cranium $n^{\circ}$ SMT-1}

As stated in the phylogenetic analysis by Orliac et al. (2010a), the most discriminative dental characters of Suoidea are to be found on the incisors and the lower dentition. Accordingly, the dental characters available on the fragmentary cranium from Şemsettin are not highly diagnostic, at least at first sight. Therefore, comparisons are made with representatives of all suprageneric groups recognized within Suoidea.

Dental morphology. Contrary to what occurs in small non-suid suoids such as Palaeochoeridae and Sanitheriidae, the upper canine SMT-1 is not labio-lingually compressed, but instead is inflated and almost circular in section (barrel-shaped). It is short and straight, and was oriented downward and slightly outward. Its ventral surface bears a third incipient enamel band, which is not present in nonsuid suoids. Among suids, the upper canines of Listriodontinae, Cainochoerinae, and Suinae display a complete ventral enamel band (van der Made, 1996a; Orliac et al., 2010a) and therefore differ from the Şemsettin specimen. The Tetraconodontinae also have an incipient lingual enamel band (e.g., Conohyus and Parachleuastochoerus), but their dental morphology differs from the specimen from Şemsettin in having a short root and a wide crown relative to root diameter. The morphology of the upper canine of SMT-1 (characters cited above) is most similar to that observed in hyotheriine suids (unfortunately conservative and monotonous; e.g., Hellmund, 1991; van der Made, 
1994, plate 115; Orliac et al., 2006, figure 3; van der Made 2010, figure 14L).

The upper $\mathrm{P} 3$ is the only available premolar. It differs from that of palaeochoerid Palaeochoerinae in having a much larger paracone, a lingual basin anteriorly delimited by a notch, and a more reduced lingual cingulum. It differs from the described species of Aureliachoerus and European Hyotherium species (Hyotheriinae) in possessing: (i) a more isometric occlusal profile, with a posterior part of the tooth wider; (ii) a paracone wider labio-lingually and a lingual basin much shallower, with a cingulum smaller; (iii) a postprotocrista finely crenulated without accessory cusp. Among Hyotherium species, the P3 from Şemsettin is morphologically close to that of the Chinese $H$. youngi (Chen, 1997) [ $=H$. shanwangense Liu et al., 2002 following van der Made (2010)]. Both taxa seem to share the characters listed above based on the illustration provided by Liu et al. (2002, figure 4B). The P3 of Nguruwe is to our knowledge only known for the species $N$. namibense (Pickford, 1986). The specimen figured by Pickford (2008, plate 1(7), plate 6(1)) shows the same morphology as regards the lingual basin as the P3 from Şemsettin. However, the P3 of $N$. namibense has distinctive proportions (posterior part slightly narrower) and it has an accessory cusp in the postparacrista (Pickford, 2008, plate 6(1)). By its morphology, the P3 from Şemsettin also strikingly recalls that of listriodont species, such as Eurolistriodon tenarezensis, Listriodon lockharti, and L. latidens (van der Made, 1996b; Orliac, 2006).

The upper molars of the cranium $n^{\circ}$ SMT-1 differ from those of palaeochoerid Palaeochoerinae in having a paraconule (= protopreconule of van der Made, 1996b) not elongated posteriorly and occupying an anterior position, in bearing four distinct roots (i.e., labial roots not fused; Figure 3 ) and a distinct posterior lobe on M3 (inferred from the shape of the outline at the neck; Figure 2.1). All those characters are diagnostic of Suidae. Besides, the groove-and-crest pattern of the upper molars from Şemsettin corresponds to that of Hyotheriinae, with simple rounded cusps and a reduced pattern of low cristae and shallow grooves (Figure 4). In the M2 from Şemsettin, the paraconule lies in a rather anterior position, but is not fused to the anterior cingulum. It is separate from the protocone by a shallow groove, still visible on the specimen despite wear, and it is not fully integrated to the preprotocrista. A paraconule fused to the anterior cingulum is considered to be a conspicuous morphological feature of Suidae, whereas this cusplet is connected to the protocone in Palaeochoeridae (van der Made, 1996a). In all known Hyotheriinae, including Nguruwe kijivium and $N$. namibense, the paraconule is fused to the anterior cingulum. However, in some Listriodontinae, such as Eurolistriodon tenarezensis (Orliac, 2006), the paraconule is neither fused to the anterior cingulum, nor fully integrated to the preprotocrista, which shows that a paraconule fused to the anterior cingulum is not strictly diagnostic of Suidae (either symplesiomorphic trait or reversal).

Size and proportions. The morphology of the upper cheek teeth indicates that the cranium from Şemsettin belongs unambiguously to Suidae, further pointing to Hyotheriinae. We compared the size and proportions of the material from Şemsettin with hyotheriine species of similar size: the European Hyotherium meisneri, Aureliachoerus aurelianensis, and Chicochoerus minus and the African Nguruwe kijivium and $N$. namibense. As illustrated by boxplots of the Antero-Posterior Length (APL; Figure 5.1) and Labio-Lingual Length (LLL; Figure 5.2 ), dimensions of the upper cheek teeth of Şemsettin are smaller than those of the smallest representative of Hyotherium, namely $H$. meisneri (van der Made, 1994), especially for the P3 and M1, larger than in C. minus (Golpe-Posse, 1972) and $N$. namibense (Pickford, 1986), and closer to those of $A$. aurelianensis and $N$. kijivium. Boxplots of the Antero-Posterior Length (APL; Figure 5.1) show that SMT-1 falls within the variability range of $A$. aurelianensis and $N$. kijivium. However, according to the available values for the Şemsettin specimen and even though most of them are under-estimated because only the base of the tooth is preserved, the LLL is somewhat distinct from that of $A$. aurelianensis, with wider $\mathrm{P} 3$ and $\mathrm{M} 1$ (18\% and $16 \%$ larger than the average size of $A$. aurelianensis, respectively; Figure 5.2). Unfortunately, P3 is, to our knowledge, undescribed for $N$. kijivium.

To sum up, dental morphology, size, and proportions of SMT-1 from Şemsettin refer it unambiguously to Suidae. Among Suidae, a referral to Hyotheriinae is also supported by the upper canine morphology (short and straight, barrel-shaped, incipient lingual enamel band, anterior groove) and the crest-and-groove pattern of the upper molars. Within Hyotheriinae, jugal teeth from Şemsettin would show the closest affinities with Aureliachoerus aurelianensis and Nguruwe kijivium as regards their APL, whereas P3 and M1 somewhat differ in their proportions wider labio-lingually. Furthermore, P3 has a very distinctive shape with respect to that of $A$. aurelianensis with a much wider and shal- 

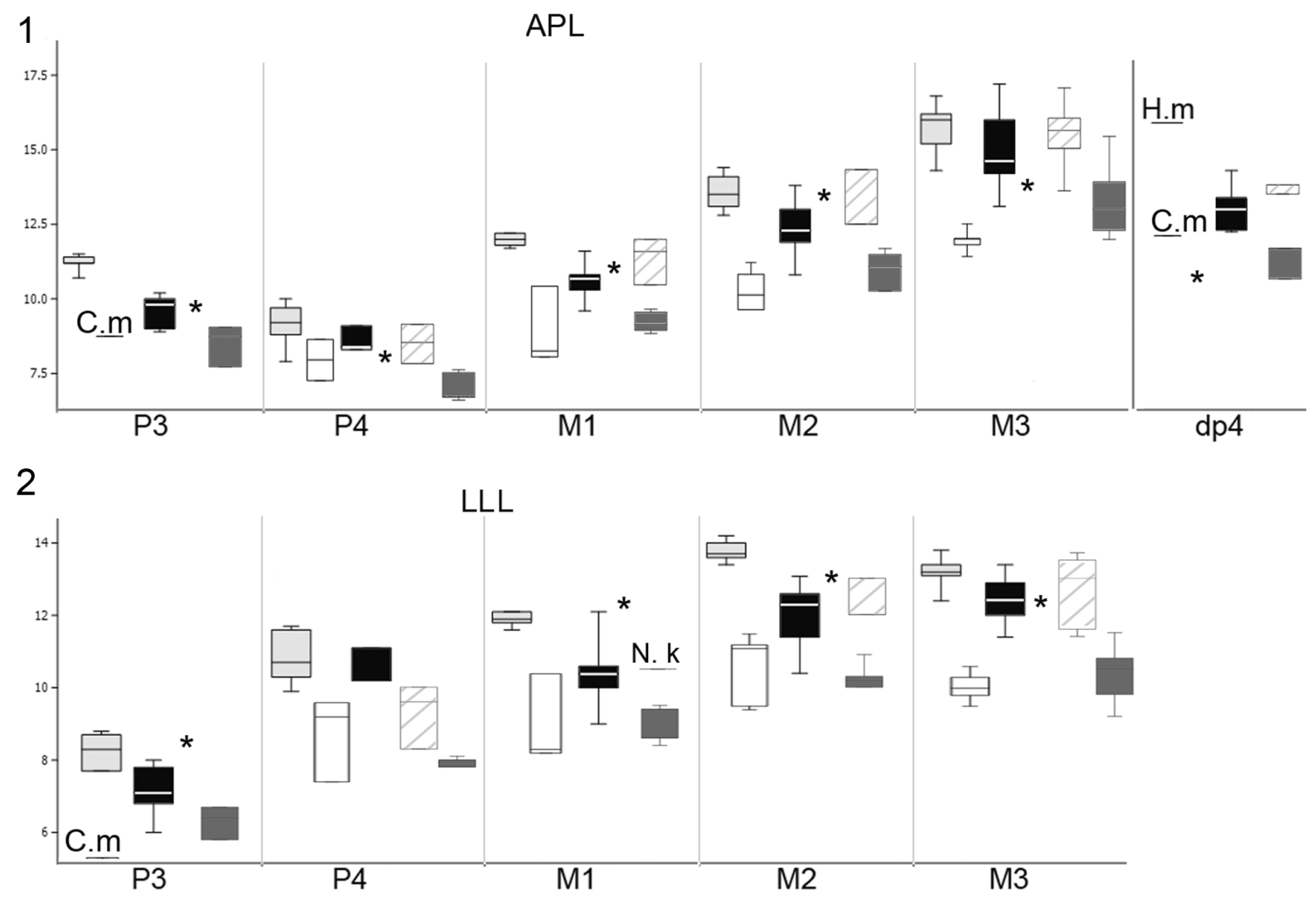

FIGURE 5. Boxplots of 1, Antero-Posterior Length (APL) and 2, Labio-Lingual Length (LLL) measurements of Hyotherium meisneri in light grey (measurements from van der Made, 1994), Aureliachoerus aurelianensis in black (measurements from the material from Artenay curated in the MNHN and from van der Made and Morales, 1999), Chicochoerus minus in white (measurements from van der Made, 1998; van der Made and Morales, 1999; Orliac et al., 2006), Nguruwe kijivium in stripes (measurements from Pickford, 1986), Nguruwe namibense in dark grey (measurements from Pickford, 2008). The specimens from Şemsettin are represented by black stars. Abbreviations: C. m, Chicochoerus minus; H. m, Hyotherium meisneri; N. k, Nguruwe kijivium.

lower lingual basin, bearing small enamel knobs. Accordingly, despite similar dimensions, the specimen SMT-1 cannot be referred to $A$. aurelianensis. $\mathrm{P} 3$ is morphologically very close to that of Hyotherium youngi, but teeth of the latter species are much larger in size (see Liu et al., 2002, table 2 for measurements). P3 also has some morphological similarities with the available specimens of $N$. namibense (morphology of the lingual basin; Pickford, 2008), but teeth of the latter species are clearly smaller in size (Figure 5). Unfortunately, as mentioned above, morphology of P3 remains unknown for $N$. kijivium, a taxon similar in size to the Şemsettin material for other teeth. The genus Nguruwe Pickford, 1986 is mostly defined by the morphology of its 11 and lower cheek teeth (Pickford, 1986; van der Made, 1996b), characters that cannot be scored on SMT-1 from Semsettin. The fact that the morphology of the P3 retrieved in
Semsettin is found in both hyotheriine species and in listriodonts suggests it is potentially plesiomorphic within Suidae. Based on the size criterion, and on the morphological correspondence of the available comparison material of $N$. kijivium and Şemsettin suid, we therefore decided to tentatively refer the fragmentary cranium from Şemsettin to the genus Nguruwe?. Such an assignment is likely to change with new findings of either the Şemsettin taxon (in Şemsettin or anywhere else) or $N$. kijivium especially if the concerned remains show diagnostic features, i.e., upper central incisor and $\mathrm{P} 3$, respectively.

\section{Assignment of the Suoid Remains from Şemsettin at the Family and Genus Level: Fourth Deciduous Lower Premolar $n^{\circ}$ SMT-2}

Size. The dp4 SMT-2 is strikingly small $(A P L=10.9$ $\mathrm{mm}$; LLL $=5.7 \mathrm{~mm}$ ). It is smaller than the specimen 
from Oberdorf, Austria, assigned by van der Made (1998) to the smallest European hyotheriine species "A. minus" (APL=12.1 mm; LLL=5.7 mm), and is close in size to the African Nguruwe namibense ( $A P L=10.7 \mathrm{~mm}$; $L L L=5.1 \mathrm{~mm}$ ). In particular, it is much smaller than what could be expected from the size of the upper molars SMT-1, which questions the occurrence of a single suoid taxon in Şemsettin. Functionally, in Suoidea, the lower dp4 occludes with the posterior part of DP3 and with the DP4. None of these teeth are documented for suoids in Şemsettin, so comparison can be made only with M1. In Şemsettin, the APL of M1 exceeds that of dp4 (11.1 mm and $10.9 \mathrm{~mm}$, respectively), whereas in most suoid species, dp4 is longer than M1 (within a given individual). In particular, it occurs in all known hyotheriine species, as illustrated by the specimens referred to Hyotherium meisneri (Figure 5.1; van der Made, 1994, table 7), to Aureliachoerus aurelianensis (Figure 5.1), and Nguruwe kijivium (Pickford, 1986). Fourth lower deciduous molars longer than M1 are also found in listriodontine suids (e.g., Eurolistriodon tenarezensis and Listriodon splendens; van der Made, 1996a; Orliac, 2007) and in the palaeochoerids Palaeochoerus and Taucanamo (M.J. Orliac, pers. obs.). Conversely, the APL of M1 also exceeds that of dp4 in the early suoid Egatochoerus jaegeri (10.0 mm in TF 2978 and $10.3 \mathrm{~mm}$ in TF 2674, respectively; Orliac et al., 2011) and in the Miocene suoid of disputed affinities Schizoporcus van der Made, 2010 (=Schizochoerus Crusafont and Lavocat, 1954; observation based on MNHN YAS TRQ 1018 and MNHN YAS TRQ 1019), keeping in mind that these comparisons are based on dp4s and M1s from distinct individuals. Be that as it may, the small size of the isolated dp4 with respect to that of M1 (from two distinct individuals) is not a sufficient criterion to exclude formally the referral of SMT-2 to the same taxon as the fragmentary cranium SMT1 , and only morphological comparison of both the crown and root patterns is thus likely to provide further information for the assignment of SMT-2.

Crown morphology. Comparison of the crown pattern of the dp4 from Şemsettin was made with other dp4s of suoids available in the literature. In particular, SMT-2 was compared to small representatives of suprageneric groups, such as Egatochoerus (Suoidea incertae sedis), the Palaeochoeridae Palaeochoerus (Palaeochoerinae) and Taucanamo (Taucanaminae), the Sanitheriidae Sanitherium, and the Suidae Eurolistriodon (Listriodontinae) and Aureliachoerus, Nguruwe, and Hyotherium (Hyotheriinae). The dp4 SMT-2 has a suid pattern, and it is still closer morphologically to that of Hyotheriinae (Figure 4.2-4). Likewise dp4 of other suids illustrated in Figure 4, SMT2 shows two external crests on the protoconid, the ectoprotocristid, and the postectoprotocristid, which are lacking in the non-suid suoids Egatochoerus and Palaeochoerus, but present in Taucanamo sansaniense. Egatochoerus and Palaeochoerus do not show any cingular structure at the protoconid and hypoconid level, whereas it is present in the suids investigated here, as well as in Sanitherium (specimen THY 9, illustrated in Bonis et al., 1997). However, in Aureliachoerus aurelianensis, the labial cingulum is reduced, and it does not extend on the labial surface of the cuspids, whereas in some specimens of the palaeochoerid T. sansaniense (e.g., MNHN Sa 4618) some cingular structures occur between the labial anterior cuspids.

The dp4 from Şemsettin presents proportions and a groove-and-crest pattern similar to that of hyotheriines, the dp4 of which is documented. Unlike in Listriodontinae, there is no endoparaconulid (=paraendoconulid, see van der Made, 1996b, figure 6 for illustration of the structure). There is no clear mesoconulid; instead of this structure lays a small enamel crest, which is even less developed than in the hyotheriines Aureliachoerus, Hyotherium, and Nguruwe kijivium. Compared to that of Sanitherium, the pattern of the dp4 from Şemsettin is simpler, with no lingual accessory cusp; SMT-2 has also a LLL higher than in Sanitherium (Bonis et al., 1997). Generally speaking, Suidae appear to have dp4s with higher LLL than other Suoidea (Figure 6).

Root pattern. Orliac et al. (2011) mentioned the fact that dp4s of Palaeochoerus and Egatochoerus have only two roots, whereas three roots are usually present in artiodactyls, including extant and extinct members of the Suidae clade, as well as Sanitheriidae (e.g., THB 9 from Chios; Bonis et al., 1997). The dp4 of the palaeochoerid Taucanamo sansaniense has no third labial pillar either (specimens MNHN Sa 9983 and Sa 4618 from Sansan, France). On the other hand, it is noteworthy that Schizoporcus vallensis from Nsebar, Bulgaria (MN9; Nikolov and Thenius, 1967) clearly shows this third labial pillar, providing further support to the hypothesis of Orliac et al. (2010a) that Schizoporcus might not be part of the palaeochoerid clade. The tooth from Şemsettin bears three root pillars, with a small labial one below the protoconid, which substantiates its assignment to Suidae and 


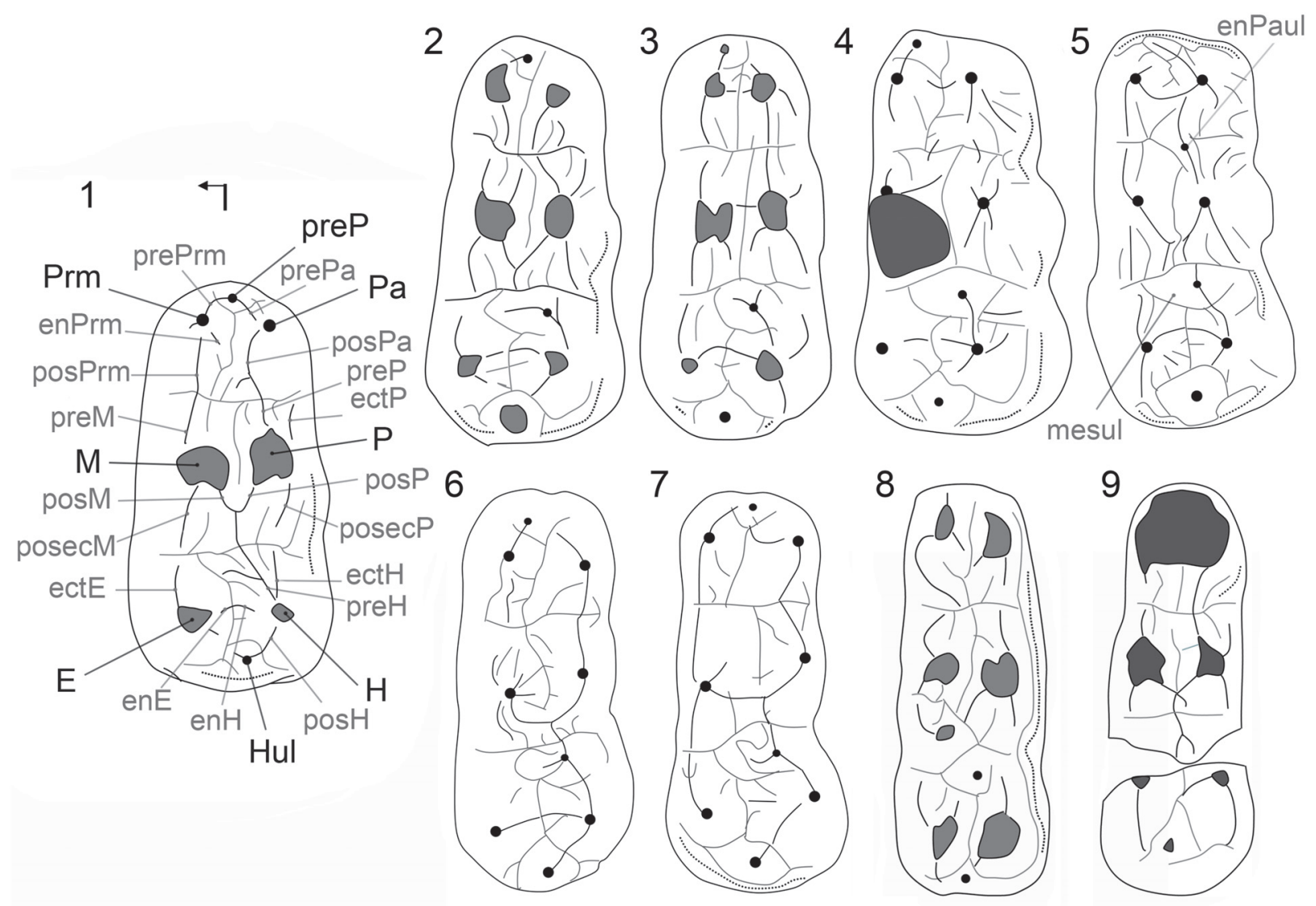

FIGURE 6. Occlusal pattern of the dp4 of: 1, specimen from Şemsettin (SMT-2); 2, Hyotherium mesneri (Suidae, Hyotheriinae, illustrated after van der Made, 1994, plate IV4b, mirror view); 3, Aureliachoerus aurelianensis (Suidae, Hyotheriinae, MNHN Ar 2566); 4, Nguruwe kijivium (Suidae, Hyotheriinae, KNM SO1062, mirror view), 5, Eurolistriodon tenarezensis (Suidae, Listriodontinae, modified after Orliac et al., 2011, figure 6H); 6, Palaeochoerus (Palaeochoeridae, modified after Orliac et al., 2011, figure 6G); 7, Egatochoerus (Suoidea incertae sedis, modified after Orliac et al., 2011, figure 6F); 8, Sanitherium (Sanitheriidae, THY 9, figured in Bonis et al., 1997); 9, Taucanamo sansaniense (MNHN Sa 4618, mirror view). All teeth represented with the same length, not to scale. Abbreviations: E, entoconid; ectE, ectoendocristid; ectH, ectohypocritid; ectP, ectoprotocristid; enE, endoentocristid; enH, endohypocritid; enPrm, endoprimocristid; H, Hypoconid; Hul, Hypoconulide; M, metacristid; P, Protoconid; Pa, paraconid; posecM, postectometacristid; posecP, postectoprotocristid; posH, posthypocristid; posM, postmetacristid; posP, postprotocristid; posPa, postparacristid; posPrm, postprimocristide; preM, premetacristid; prep, preprotocristide; prePa, preparacristid; prePrm, preprimonid; Prm, primonid.

further discounts its referral to the Palaeochoeridae.

To conclude, in both a morphological and metrical perspective, the isolated dp4 from Şemsettin strongly resembles dp4s of hyotheriines, as it has been compared to in the present study. As such, it can be referred to as a hyotheriine with confidence. However, its size is much smaller than that of any dp4 of Hyotherium, Aureliachoerus aurelianensis (Figure 5), and Chichoerus minus, and similar in size to that of Nguruwe namibense, which may indicate the occurrence of two distinct hyotheriine taxa in Şemsettin. The co-occurrence of two species of Hyotheriinae is frequently recorded in Mio- cene localities (e.g., van der Made, 2010, figure 36) and this hypothesis is proposed here.

\section{Short Overview of the Small Suoids from the Early Miocene of the Old World}

Turkey is located at the crossroads of Europe, Asia, and Arabo-Africa. The remains from Şemsettin are the first suoid remains known for the early Miocene of Anatolia. In Europe, the taxonomic assignment of small- to medium-sized suoids documented during the MN3-4 interval ( $20-17 \mathrm{Ma})$ is variable depending on the authors. According to the recent revision of van der Made (2010), Hyotheriinae are represented by two genera: Hyotherium 
Von Meyer, 1834, with $H$. major and $H$. soemmeringi wylensis, and Aureliachoerus Ginsburg, 1974 with $A$. minus and $A$. aurelianensis. This opinion contrasts with the result of the formal parsimony analysis of Orliac et al. (2006), which found [A. minus + A. aurelianensis] to be paraphyletic within Hyotheriinae and led to the erection of the monotypic genus Chicochoerus for C. minus [see Material and Methods section]. A third Hyotherium species, namely $H$. lacaillei Orliac et al., 2006, has subsequently been considered junior synonym of $H$. soemmeringi wylensis by van der Made (2010). The latter author questioned the validity of some diagnostic characters of Orliac et al. (2006), such as the lack of diastema or the lingual position of the $\mathrm{P} 1$ in $H$. lacaillei, considering that "diastemas are no grounds to recognize a new species" (van der Made, 2010, p. 91) and that contrary to Orliac et al.'s (2006) observations, the position of $\mathrm{P} 1$ relative to the canine is due to the lack of diastema, which is, again, no grounds to recognize a new species. The material from Montréal-du-Gers is characterized by wide and globular upper premolars; unfortunately, bivariate diagrams of upper cheek teeth have not been provided by van der Made (2010) to substantiate his statement. Based on the measurements of $H$. soemmeringi wylensis provided by van der Made (2010) and our own observations on $H$. lacaillei, the APL/LLL ratio differs on P1-P2 (only premolars for which the measurements are available in $H$. lacaillei). On P1, the APL/LLL ratio in $H$. lacaillei equals 1.8 vs. $2.0-2.2$ in $H$. soemmeringi wylensis; on $\mathrm{P} 2$, the APL/LLL ratio in $H$. lacaillei $=$ 1.6 vs. $1.9-2.3$ in $H$. soemmeringi wylensis. In the concerned discussion, van der Made (2010) also completely omitted mentioning and/or discussing the morpho-anatomical features from the lower dentition listed in the original differential diagnosis of $H$. lacaillei by Orliac et al. (2006). As a consequence, we do consider these taxa as distinct taxonomic entities.

Palaeochoeridae are also represented in Europe during the early Miocene, with only one species, Taucanamo primum, according to van der Made (2010), or with two species, T. primum and T. grandaevum, according to Orliac et al. (2006). These two species are recognized as Pecarichoerus primus and Choeromorus grandaevus, respectively, according to Pickford (2011). Be as it may, such a taxonomic controversy is far beyond the scope of the present work.

Very few data are available for the early Miocene interval in Asia. In a review of small suoids from the Miocene of Europe and Asia, Pickford
(2011) mentioned the presence of the palaeochoerid Pecarichoerus sminthos in Pakistan in "Bugti" and "Paali D-C2" [sic] for a time interval corresponding to the MN4 biozone ( 17 Ma). However, "Bugti" is not a locality but the name of a tribal territory, in which dozens of vertebrate localities range from the middle Eocene up to the Pleistocene (Welcomme et al., 1997, 1999, 2001; Métais et al., 2009a; Antoine et al., 2013). The locality of Paali DB-C2 has been dated from the early Oligocene, based on a species-rich mammalian fauna including a wide array of micro- , meso-, and mega-mammals (for review, see Marivaux et al., 1999, 2001; Antoine et al., 2003, 2004; Marivaux et al., 2005; Adnet et al., 2007; Métais et al., 2009a, 2009b; Antoine et al., 2013). The suoid assemblage of Paali DB-C2 was studied by Orliac et al. (2010b). The other occurrence of $P$. sminthos in the Tertiary of the Bugti Hills is based on a specimen described by Forster-Cooper (1913, p. 514) and originating "from the Upper Oligocene deposits of Dera Bugti" (see Antoine et al., 2013). The only palaeochoerid recognized from the early Miocene of the Sulaiman Province thus far in a well-constrained stratigraphic context is Pecarichoerus sp. from the Samane locality ("level 4", earliest Miocene; MN2; Antoine et al., 2013, p. 414). Sanitheriidae occur throughout the Chitarwata and Vihowa formations (Lindsay et al., 2005; Orliac et al., 2009, $2010 b)$ and are therefore a conspicuous component of the suoid fauna of the early Miocene of Sulaiman province (Pakistan). Concerning small Suidae, a few specimens from the early Oligocene locality of Paali C2, referred to Hyotherium, remain unidentified at species level (Orliac et al., 2010b), but there is no specimen referable to Hyotherium in the early Miocene localities of Sulaiman province, to our knowledge.

In central Asia, a small suid referred to "Conohyus" betpakdalensis by Trofimov (1949) has been described from the Askazansor Formation in Betpakdala, South Kazakhstan (MN 2-3, early Miocene; Kordikova, 2001). This material was subsequently placed in the genus Xenohyus (Hyotheriinae) by van der Made (1994).

In eastern Asia, few suoid remains have been described from the early Miocene locality of Hang Mon, Vietnam (Ginsburg et al., 1992; Covert et al., 2001; Böhme et al., 2011). Ginsburg et al. (1992) described a M3, which they attributed to Hyotherium cf. soemmeringi based on its morphology and dimensions (APL=16.7 mm; LLL=15.3 mm). Covert et al. (2001) described an m2 and a P4 from the same locality and referred to as Chleuastochoerus 
stehlini. The small size of the mesoconulid and hypoconulid of the $\mathrm{m} 2$ would rather suggest an assignment of this material to Hyotherium instead of to Chleuastochoerus. In China, the late earlyearly middle Miocene locality of Shanwang has yielded two Hyotheriinae species: Sinapriculus linquensis and Hyotherium shanwangense (Liu et al., 2002). However, van der Made (2010) considered that differences in size and morphology between these two taxa were due to sexual dimorphism, and that both $S$. linquensis and $H$. shanwangense were junior synonyms of Miochoerus youngi Chen, 1997, erected for a suid mandible from Jianshan (Xinan, China), correlated to MN6 according to van der Made (2010). In the same work, this author attributed the latter taxon to the new binomen Hyotherium youngi (Chen, 1997). Some other Suidae material has been mentioned in the early Miocene of Japan (Takai, 1950, 1954; Oshima et al., 2008), but it is lacking any diagnostic feature and it was attributed to Suidae gen. et $\mathrm{sp}$. indet. by Oshima et al. (2008).

In Africa, early Miocene small suoids are represented by the genus Nguruwe Pickford, 1986 with the species Nguruw kijivium (Wilkinson, 1976) and Nguruwe namibense (Pickford, 1986), and the genus Kenyasus Pickford, 1986 with the species Kenyasus rusingensis Pickford, 1986 and Kenyasus namaquensis Pickford and Senut, 1997 (Bishop, 2010). Those two genera have been placed in the Kubanochoerinae Suidae by Pickford (1986). Nguruwe was considered as a representative of Listriodontinae Suidae by van der Made (1996b), whereas Kenyasus has tentatively been placed in the Cainochoerinae Suidae by van der Made (2010) but with no further argument. According to the results of the phylogenetic analysis of Orliac et al. (2010a), Nguruwe is part of the hyotheriine clade, whereas Kenyasus lies in a more basal position within the Suidae clade, as sister taxon to the [Cainochoerinae, [[Suinae, Tetraconodontinae], Hyotheriinae]] clade.

\section{Paleoecological and Paleobiogeographical Considerations}

The depositional environment of the Şemsettin vertebrate-yielding levels was a near-shore sandbar along the coast of a lake with highly fluctuating levels, in contact with the Neo-Tethyan suture (Karadenizli, 2011). The Şemsettin fauna includes two obligate arboreal micromammals (the sciurid Aliveria and the glirid Glirudinus), together with a forest dweller (the small moschid Micromeryx; Sen et al., 1998; Karadenizli, 2011). Those mamals point to a forested milieu neighboring a lake, with fluctuating environmental conditions, due to regional tectonics. The general morphology of the small bunodont hyotheriine taxa from Şemsettin is compatible with such a hypothesized forest environment.

The suid-yielding Şemsettin assemblage does not include any undisputable Afro-Arabian component (e.g., elephantoids and deinotheres; tubulidentates; hyracoids; primates). However, another fossiliferous level from Şemsettin, located only a few meters above in the same section, has yielded tooth fragments unambiguously referable to elephantoid proboscideans, yet unidentified at the family, genus, or species level (Sen et al., 1998, p. 313). The age of the Şemsettin section as a whole was correlated with the late early Miocene MN4 biozone (Karadenizli, 2011). These are the oldest specimens of Afro-Arabian migrants from the "Proboscidean Datum Event" known thus far in Anatolia. On the other hand, this major phase of transcontinental dispersal for land mammals is widely recognized in younger Anatolian localities such as Çandir (MN5; Geraads et al., 2003; Karadenizli, 2011) or Kultak in SW Anatolia (MN5-6 transition; Kayserı Özer et al., 2014).

Noteworthy, the size and general morphology of Nguruwe kijivium and the morphology of P3 of the small Nguruwe namibense from Africa are close to those of the Şemsettin hyotheriine as documented by SMT-1. Unfortunately, the available material for comparison between $N$. kijivium and the Şemsettin suid material is too scarce to properly confirm their congeneric assignment (i.e., lack of upper central incisors and lower cheek teeth), and our referral of the cranium SMT-1 to Nguruwe could be challenged by the collection of any additional material. Besides, by the morphology of its P3, the fragmentary cranium SMT-1 shows closer affinities with the Chinese Hyotherium species from Shanwang than with any other hyotheriine taxon from Eurasia, a statement which may alternately support the hypothesis of privileged relationships with Asia. Based on the available characters of the holotype and only undisputable specimen of $\mathrm{Ngu}$ ruwe? galaticum sp. nov., this taxon shows equal affinities with Asiatic and African Hyotheriinae, which is not that surprising in the context of generalized transcontinental dispersals in the late early Miocene of the Old World, as recorded by land mammals (e.g., Antoine et al., 2013; Sen, 2013). Conversely, the isolated dp4 SMT-2, whose referral to the same taxon as SMT-1 is questionable due to its diminutive size, is morphologically closer to the 
European hyotheriine species than to the African taxon Nguruwe.

The onset of Afro-Arabian influence in Anatolian Neogene mammalian faunas $\left(\begin{array}{lll}\sim & \mathrm{Ma}\end{array}\right)$ appears to be delayed with respect to what is observed in other areas of Asia and Europe, as the earliest record of massive Afro-Arabian immigrants is unambiguously attested in South Asia from 22$23 \mathrm{Ma}$ onward (MN1-2; Antoine et al., 2013) and from 18 Ma onward in western Europe (MN3-4 transition; e.g., Sen, 2013). This anomaly, in particular given the privileged geographic situation of Anatolia, further testifies to the considerable incompleteness of the early Miocene fossil record in Turkey and surrounding areas. The timing of the early Miocene faunal interchanges between Eurasia and Afro-Arabia will not be elucidated until more efforts are undertaken for finding mammals in these regions and intervals.

\section{CONCLUSIONS}

The fragmentary cranium and the isolated dp4 from the Şemsettin locality (Kumartaş Formation, Çankiri-Çorum Basin) document the first suoids ever recorded in the early Miocene of Anatolia. Both remains can be attributed to the Hyotheriinae with confidence, but the small size of the isolated dp4 relative to that of the corresponding occluding tooth on the fragmentary cranium led us to propose the co-occurrence of two distinct hyotheriine species in Şemsettin: Nguruwe? galaticum sp. nov. and another, smaller, hyotheriine of unidentified affinities. The dental characters available on the fragmentary cranium from Şemsettin are not highly diagnostic, making its generic referral difficult to assess. Based on similar size and close morphology to Nguruwe kijivium, we tentatively refer the cranium from Şemsettin to Nguruwe? galaticum sp. nov. This new taxon shows equal affinities with both early Miocene Asiatic and African Hyotheriinae.

The earliest record of Afro-Arabian mammal immigrants in Anatolia ( 17 Ma) appears to be somewhat delayed with respect to South Asia ( 22-23 Ma) and, to a lesser extent, Western Europe ( 18 Ma), which in turn confirms the drastic incompleteness of the early Miocene Anatolian continental fossil record.

\section{ACKNOWLEDGMENTS}

We are grateful to A. Lethiers (UPMC) for drawing of the map and stratigraphic column, to A.L. Charruault (ISE-M) for the restauration of the
SMT-1 specimen and to R. Lebrun (ISE-M) for its help in data acquisition (CT scan). Many thanks to M. Pickford (Collège de France) for providing access to cast of the sanitheriid milk teeth from Chios, Greece. Data presented in this work were produced through the technical facilities of the MRI platform and of the labEx CeMEB. This is ISE-M Publication ISEM 2015-084 SUD.

\section{REFERENCES}

Adnet, S., Antoine, P.-O., Baqri, S.R.H., Crochet, J.-Y., Marivaux, L., Welcomme, J.-L., and Métais, G. 2007. New tropical carcharhinids (chondrichthyes, Carcharhiniformes) from the late Eocene-early Oligocene of Balochistan, Pakistan: Paleoenvironmental and paleogeographic implications. Journal of Asian Earth Sciences, 30:303-323.

Antoine, P.-O., Ducrocq, S., Marivaux, L., Chaimanee, Y., Crochet, J.-Y., Jaeger, J.-J., and Welcomme, J.-L. 2003. Early rhinocerotids (Mammalia, Perissodactyla) from South Asia and a review of the Holarctic Paleogene rhinocerotid record. Canadian Journal of Earth Sciences, 40:365-374.

Antoine, P.-O., Shah, S.M.I., Cheema, I.U., Crochet, J.Y., de Franceschi, D., Marivaux, L., Métais, G., and Welcomme, J.-L. 2004. New remains of the baluchithere Paraceratherium bugtiense (Pilgrim, 1910) from the Late/latest Oligocene of the Bugti Hills, Balochistan, Pakistan. Journal of Asian Earth Sciences, 24:71-77.

Antoine, P.-O., Downing, K.F., Crochet, J.-Y., Duranthon, F., Flynn, L.J., Marivaux, L., Métais, G., Rajpar, A.R., and Roohi, G. 2010. A revision of Aceratherium blanfordi Lydekker, 1884 (Mammalia: Rhinocerotidae) from the early Miocene of Pakistan: postcranials as a key. Zoological Journal of the Linnean Society, 160:139-194.

Antoine, P.-O., Métais, G., Orliac, M.J., Crochet, J.-Y., Flynn, L.J., Marivaux, L., Rajpar, A.R., Roohi, G., and Welcomme, J.-L. 2013. Mammalian Neogene biostratigraphy of the Sulaiman Province, Pakistan, p. 400-422. In Wang, X., Flynn, L.J., and Fortelius, M., (eds.), Fossil mammals of Asia: Neogene Biostratigraphy and Chronology. Columbia University Press, New York.

Bishop, L. 2010. Suoidea, p. 821-842. In Werdelin, L. and Sanders, W.J. (eds.), Cenozoic mammals of Africa. University of California Press, Berkley.

Böhme, M., Prieto, J., Schneider, S., Hung, N.V., Quang, D.D., and Tran, D.N. 2011. The Cenozoic on-shore basins of Northern Vietnam: Biostratigraphy, vertebrate and invertebrate faunas. Journal of Asian Earth Sciences, 40:672-687.

Boisserie, J.-R., Lihoreau, F., Orliac, M.J., Fisher, R., Weston, E., and Ducrocq, S. 2010. Morphology and phylogenetic relationships of the earliest known hippopotamids (Cetartiodactyla, Hippopotamidae, Ken- 
yapotaminae). Zoological Journal of the Linnean Society, 158:325-367.

Chen, G.F. 1997. A new suid from the Middle Miocene of Xinan, Henan, p. 129-136. In Ton, Y.S. Zhang, Y.Y., Wu, W.Y., Li, J.L., and Shi, L.Q. (eds.), Evidence for evolution - essays in honor of Prof. Chungchien Young on the hundredth anniversary of his birth. China Ocean Press, China.

Collier, A. and Guex, H. 1977. Un crâne d'Aureliachoerus aurelianensis (Mammalia, Artiodactyla) dans le Burdigalien de La Romieu (Gers). Bulletin de la Société Archéologique et Historique du Gers, 4:463470.

Cope, E.D. 1888. The Artiodactyla. American Naturalist, 22:1079-1095.

Covert, H.H., Hamrick, M.V., Dzanh, T., and McKinney, K.C. 2001. Fossil mammals from the Late Miocene of Vietnam. Journal of Vertebrate Paleontology, 21:633636.

Crusafont, M. and Lavocat, R. 1954. Schizochoerus un nuevo género de Suidos del Pontienese inferior (Vallesiense) del Valles Penedes. Notas y Comunicaciones del Instituto Geológico y Minero de España, 36:79-90.

de Bonis, L., Koufos, G.D., and Sen, S. 1997. The sanitheres (Mammalia, Suoidea) from the Middle Miocene of Chios island, Aegean sea, Greece. Revue de Paléobiologie de Genève, 16:259-270.

Forster Cooper, C. 1913. The Anthracotheriidae of the Dera Bugti deposits in Baluchistan. Memoirs of the Geological Survey of India, 4:1-59.

Geraads, D., Begun, D.R., and Güleç, E. 2003. The Middle Miocene hominoid site of Çandir, Turkey: general paleoecological conclusions from the mammalian fauna, p. 241-250. In Güleç, E., Begun, D.R., and Geraads, D. (eds.), Geology and Vertebrate Paleontology of the Middle Miocene Hominoid Locality Çandir. Courier Forschung Institut Senckenberg, Frankfurt.

Ginsburg, L. 1974. Les Tayassuidés des phosphorites du Quercy. Palaeovertebrata, 6:55-85.

Ginsburg, L., Minh, L. van, Nam, K.Q., and Thuan, D. van. 1992. Premières découvertes de vertébrés continentaux dans le Néogène du Nord du Vietnam. Comptes Rendus de l'Académie des Sciences, Paris, Série II, 314:627-630.

Golpe-Posse, J.M. 1972. Suiformes del Terciario Español y sus yacimientos. Paleontología y Evolución, 2:1-197.

Gray, J.E. 1821. On the natural arrangement of vertebrose animals. London Medical Repository, 15:296310.

Hellmund, M. 1991. Schweineartige (Suina, Artiodactyla, Mammalia) aus oligo-mioznen Fundstellen Deutschlands, der Schweiz und Frankreichs I. Hyotherium meissneri (Suidae) aus dem Untermiozän von UlmWesttangente (Baden-Würtenberg). Stuttgarter Beitrage zur Naturkunde (Serie B Geologie und Palontologie), 176:1-69.
Karadenizli, L. 2011. Oligocene to Pliocene palaeogeographic evolution of the Çankırı-Çorum Basin, Central Anatolia, Turkey. Sedimentary Geology, 237:129.

Karadenizli, L, Saraç, G., Şen, Ş., Seyitoğlu, G., Antoine, P.-O., Kazancı, N., Varol, B., Alçiçek, M.C., Gül, A., Erten, H., Esat, K., Özcan, F., Savaşçı, D., Antoine, A., Filoreau, X., Hervet, S., Bouvrain, G., de Bonis, L., and Hakyemez, H.Y. 2004. Çankırı-Çorum havzasının batı ve güney kesiminin memeli fosillere dayalı Oligo-Miyosen biyostratigrafisi ve dolgulama evrimi. MTA report no 10706.

Kaymakçı, N. 2000. Tectono-stratigraphical evolution of the Çankırı Basin (Central Anatolia, Turkey). Geologia Ultraiectina, 190:1-247.

Kaymakçı, N., Özçelik, Y., White, S.H., and Van Dijk, P.M. 2009. Tectono-stratigraphy of the Çankırı Basin: Late Cretaceous to early Miocene evolution of the Neotethyan Suture Zone in Turkey, p. 67-106. In Van Hinsbergen, D.J.J., Edwards, M.A., and Govers, R. (eds.), Collision and Collapse at the Africa-ArabiaEurasia Subduction Zone. The Geological Society, London, Special Publications 311, London.

Kaymakçı, N., Özmutlu, S., Van Dijk, P.M., and Özçelik, Y. 2010. Surface and subsurface characteristics of the Çankırı Basin (Central Anatolia, Turkey): Integration of remote sensing, seismic interpretation and gravity. Turkish Journal of Earth Sciences, 19:79100.

Kayserı Özer, M.S., Akgün, F., Mayda, S., and Kaya, T. 2014. Palynofloras and vertebrates from Muğla-Ören region (SW Turkey) and palaeoclimate of the Middle Burdigalian-Langhian period in Turkey. Bulletin of Geosciences, 89:137-162.

Kordikova, E.G. 2001. Remarks on the Oligocene-Miocene mammal palaeontology and sequence stratigraphy of South-Western Betpakdala Steppe, South Kazakhstan. Neues Jahrbuchfür Geologie und Paläontologie (Abhandlungen), 221:35-79.

Lindsay, E.H., Flynn, L.J., Cheema, I.U., Barry, J.C., Downing, K.F., Rajpar, A.R., and Raza, S.M. 2005. Will Downs and the Zinda Pir Dome. Palaeontologia Electronica, 8:1-19.

Liu, Li-Ping, Fortelius, M., and Pickford, M. 2002. New fossil Suidae from Shanwang, Shandong, China. Journal of Vertebrate Palaeontology, 22:152-163.

Madden, C.T. and Van Couvering, J.A. 1976. The Proboscidean Datum Event: early Miocene migration from Africa. Geological Society of America Abstracts with Programs: 992.

Marivaux, L., Antoine, P.-O., Baqri, S.R.H., Benammi, M., Chaimanee, Y., Crochet, J.-Y., de Franceschi, D., Iqbal, N., Jaeger, J.-J., Métais, G., Roohi, G., and Welcomme, J.-L. 2005. Anthropoid primates from the Oligocene of the Bugti Hills (Pakistan): Data on early anthropoid evolution and biogeography. Proceedings of the National Academy of Sciences of the United States of America, 102:8436-8441. 
Marivaux, L., Vianey-Liaud, M., and Welcomme, J.-L. 1999. Première découverte de Cricetidae (Rodentia, Mammalia) dans le synclinal Sud de Gandoï (Bugti Hills, Balouchistan, Pakistan). Comptes rendus de l'Académie des Sciences, Paris, 329:839-844.

Marivaux, L., Welcomme, J.-L., Antoine, P.-O., Métais, G., Baloch, I., Benammi, M., Chaimanee, Y., Ducrocq, S., and Jaeger, J.-J. 2001. A fossil lemur from the Oligocene of Pakistan. Science, 294:587591.

Métais, G., Antoine, P.-O., Baqri, S.R.H., Crochet, J.-Y., de Franceschi, D., Marivaux, L., and Welcomme, J.L. 2009a. Lithofacies, Depositional Environments, Regional Biostratigraphy and Age of the Chitarwata Formation in the Bugti Hills, Balochistan, Pakistan. Journal of Asian Earth Sciences, 34:154-167.

Métais, G., Welcomme, J.-L., and Ducrocq, S. 2009b. Lophiomerycid ruminants from the Oligocene of the Bugti Hills (Balochistan, Pakistan). Journal of Vertebrate Paleontology, 29:1-12.

Nikolov, I. and Thenius, E. 1967. Schizochoerus (Suidae, Mammalia) aus dem Pleistozän von Bulgarien. Annalen des Naturhistorischen Museums, 71:329340.

Orliac, M.J. 2006. Eurolistriodon tenarezensis sp. nov., from Montréal-du-Gers (France): implications for the systematics of the European Listriodontinae (Suidae, Mammalia). Journal of Vertebrate Paleontology, 26:967-980.

Orliac, M.J. 2007. Le rôle des Listriodontinae dans la différenciation des Suidae (Mammalia); Paléoanatomie, Systématique, Phylogénie. Unpublished PhD Thesis, Université Pierre et Marie Curie, Paris, France.

Orliac, M.J., Antoine, P.-O., and Ducrocq, S. 2010a. Phylogenetic relationships of the family Suidae; new insights on the relationships among Suoidea. Zoologica Scripta, 39:315-330.

Orliac, M.J., Antoine, P.-O. and Duranthon F. 2006. The Suoidea (Mammalia, Artiodactyla), exclusive of Listriodontinae, from the early Miocene of Béon 1 (Montréal-du-Gers, SW France, MN4). Geodiversitas, 28:685-718.

Orliac, M.J., Antoine, P.-O., Métais, G., Crochet, J.-Y., Marivaux, L., Roohi, G., and Welcomme, J.-L. 2009. Listriodon guptai Pilgrim, 1926 (Mammalia, Suidae) from the early Miocene of the Bugti Hills, Balochistan, Pakistan: new insights into early Listriodontinae evolution and biogeography. Naturwissenschaften, 96:911-920.

Orliac, M.J., Antoine, P.-O., Roohi, G., and Welcomme, J.-L. 2010b. Suoidea (Mammalia, Cetartiodactyla) from the early Oligocene of the Bugti Hills, Balochistan, Pakistan. Journal of Vertebrate Paleontology, 30:1300-1305.

Orliac, M.J., Guy, F., Chaimanee, Y., Jaeger, J.-J., and Ducrocq, S. 2011. New remains of Egatochoerus jaegeri (Cetartiodactyla, Mammalia) from the late Eocene of Thailand. Palaeontology, 54:1323-1335.
Oshima, M., Tomida, Y, Araki, T., and Azuma, Y. 2008. First record of the genus Hyotherium (Mammalia: Suidae) from Japan. Memoir of the Fukui Prefectural Dinosaur Museum, 7:25-32.

Owen, R. 1848. On the archetype and homologies of the vertebrate skeleton. Van Voorst, London, United Kingdom.

Özcan, F., Karadenizli, L., Sen, S., Saraç, G., and Seyitoğlu, G. 2007. Lithostatigraphy and mammalian fossil content of Lower Miocene deposits in the western part of Çankırı Basin: A test for post-collisional tectonic models of NW Central Anatolia. Geological Bulletin of Turkey, 50:150-157.

Pickford, M. 1986. A revision of the Miocene Suidae and Tayassuidae (Artiodactyla, Mammalia) of Africa. Tertiary Research (Special Paper), 7:1-83.

Pickford, M. 2008. Suidae from the Early Miocene of the northern Sperrgebiet, Namibia. Memoirs of the Geological Survey of Namibia, 20:365-385.

Pickford, M. 2011. Small suoids from the Miocene of Europe and Asia. Estudios Geológicos, 67:541-578.

Pickford, M. and Senut, B. 1997. Cainozoic mammals from coastal Namaqualand, South Africa. Paleontologia Africana, 34:199-217.

Sen, S. 2013. Dispersal of African mammals in Eurasia during the Cenozoic: Ways and whys. Geobios, 46:159-172.

Sen, S., Seyitoğlu, G., Karadenizli, L., Kazancı, N., Varol, B., and Araz, H. 1998. Mammalian biochronology of Neogene deposits and its correlation with the lithostratigraphy in the Çankırı-Çorum Basin, Central Anatolia, Turkey. Eclogae Geologica Helvetiae, 91:307-320.

Seyitoğlu, G., Aktuğ, B., Karadenizli, L., Kaypak, B., Şen, Ş., Kazancı, N., Işık, V., Esat, K., Parlak, O., Varol, B., Saraç, G., and İleri, İ. 2009. A Late Pliocene Quaternary pinched crustal wedge in NW Central Anatolia, Turkey: A neotectonic structure accommodating the internal deformation of the Anatolian Plate. Geological Bulletin of Turkey, 52:121-154

Takai, F. 1950. About the Fossil wild boar from Tsuyama Basin. Journal of Geological Society, Japan, 56:278279.

Takai, F. 1954. An addition to the Mammalian fauna of the Japanese Miocene. Journal of Faculty of Science, University of Tokyo, Section of Geology, 9:331335.

Tassy, P. 1990. The "Proboscidean Datum Event": How many proboscideans and how many events?, p. 237252. In Lindsay, E.H., Fahlbusch, V., and Mein, P. (eds.), European Neogene Mammal Chronology. Plenum Press, New York.

Trofimov, B.A. 1949. The oldest representative of the primitive pigs in Asia. Doklady Akademia Nauk SSR, 67:145-148. [In Russian].

van der Made, J. 1994. Suoidea from the Lower Miocene of Cetina de Aragón (Spain). Revista Española de Paleontología, 9:1-23. 
van der Made, J. 1996a, Albanohyus, a small pig (Suidae) of the Middle Miocene. Acta Zoologica Cracoviense, 39:293-303.

van der Made, J. 1996b. Listriodontinae (Suidae, Mammalia), their evolution, systematics and distribution in time and space. Contributions to Tertiary and Quaternary Geology, 33(1-4):3-254.

van der Made, J. 1998. Aureliachoerus from Oberdorf and other Aragonian pigs from Styria. Annalen des Naturhistorischen Museums in Wien, 99:225-277.

van der Made, J. 2010. The pigs and "Old World peccaries" (Suidae and Palaeochoeridae, Suoidea, Artiodactyla) from the Miocene of Sandelzhausen (southern Germany): phylogeny and an updated classification of the Hyotheriinae and Palaeochoeridae. Paläontologische Zeitschrift, 84:43-121.

van der Made, J. and Morales, J. 1999. Aureliachoerus (Suidae, Mammalia) from Agreda and other Miocene localities of Spain. Geobios, 32: 901-914.

Von Meyer, H. 1834. Die fossilen Zähne und Knochen von Georgensgmünd in Bayern. Sauerlander, Frankfurt am Main.
Welcomme, J.-L., Antoine, P.-O., Duranthon, F., Mein, P., and Ginsburg, L. 1997. Nouvelles découvertes de Vertébrés miocènes dans le synclinal de Dera Bugti (Balouchistan, Pakistan). Comptes Rendus de l'Académie des Sciences, Sciences de la Terre et des Planètes, 325:531-536.

Welcomme, J.-L., Benammi, M., Crochet, J.-Y., Marivaux, L., Métais, G., Antoine, P.-O., and Baloch, I. 2001. Himalayan Forelands: Palaeontological evidence for Oligocene detritic deposits in the Bugti Hills (Balochistan, Pakistan). Geological Magazine, 138:397-405.

Welcomme, J.-L., Marivaux, L., Antoine, P.-O., and Benammi, M. 1999. Mammifères fossiles des Collines Bugti (Balouchistan, Pakistan). Nouvelles données. Bulletin de la Société d'Histoire Naturelle de Toulouse, 135:135-139.

Wilkinson, A.F. 1976. The lower Miocene Suidae of Africa, p. 173-282. In Savage, R.J.G. and Coryndon, S.C. (eds.), Fossil Vertebrates of Africa. Academy Press, London/New York. 